\title{
PELATIHAN PEMBUATAN DESINFEKTAN DAN HAND SANITIZER DENGAN PENAMBAHAN AROMA ALAMI SEBAGAI UPAYA PENCEGAHAN PENULARAN VIRUS COVID-19
}

\section{Training In Making Disinfectant And Hand Sanitizer With The Addition Of Natural Aroma As An Effort To Prevent The Transmission Of The Covid-19 Virus}

\author{
Poedji Loekitowati Hariani ${ }^{1 *}$, Salni ${ }^{2}$, Muhammad Said ${ }^{1}$, Fatma ${ }^{1}$, Dedi Rohendi ${ }^{1}$ \\ ${ }^{1}$ Jurusan Kimia, Fakultas Matematika dan Ilmu Pengetahuan Alam, Universitas Sriwijaya, \\ ${ }^{2}$ Jurrusan Biologi, Universitas Sriwijaya
}

Jl. Palembang-Prabumulih Km 32, Indralaya OI 30662 , Sumatera Selatan, Indonesia

Alamat korespondensi: puji_lukitowati@mipa.unsri.ac.id

(Tanggal Submission: 5 Mei 2021, Tanggal Accepted : 19 Agustus 2021)

\begin{abstract}
Kata Kunci : Abstrak :
desinfektan; Desinfektan dan hand sanitizer merupakan bahan kimia yang sering digunakan hand sanitizer; untuk pencegahan penularan virus covid-19. Mahalnya harga desinfektan dan ekstrak daun hand sanitizer, serta banyaknya informasi secara online tentang pembuatan serai; covid-19 kedua bahan tersebut maka banyak masyarakat yang membuat desinfektan dan hand sanitizer sendiri. Pembuatan desinfektan dan hand sanitizer tanpa memiliki pengetahuan yang cukup justru memiliki resiko terhadap kesehatan dan lingkungan. Kegiatan pengabdian masyarakat ini bertujuan memberikan pelatihan pembuatan desinfektan dan hand sanitizer yang tepat yaitu sesuai standar WHO, dengan penambahan aroma alami ekstrak daun serai. Ekstrak daun serai bersifat antibakteri, antiseptik dan memiliki aroma yang segar. Kegiatan juga memberikan pelatihan cara penggunaaan desinfektan dan hand sanitizer yang tepat. Khalayak sasaran dalam kegiatan ini adalah masyarakat dusun IV desa Tanjung Seteko, kecamatan Indralaya, Ogan Ilir. Hasil kegiatan menunjukkan meningkatnya pemahaman dan ketrampilan masyarakat dalam pembuatan desinfektan dan hand sanitizer yang dibuat dengan penambahan ekstrak daun serai.
\end{abstract}

Panduan sitasi / Citation guidance (APPA $7^{\text {th }}$ edition) :

Hariani, P.L., Salni, Said, M., Fatma, \& Rohendi, D. (2021). Pelatihan Pembuatan Desinfektan Dan Hand Sanitizer Dengan Penambahan Aroma Alami Sebagai Upaya Pencegahan Penularan Virus Covid-19. Abdi Insani, 8 (2), 198-204. http://doi.org/10.29303/abdiinsani.v8i2.394 


\section{PENDAHULUAN}

COVID-19 (coronavirus disease 2019) merupakan penyakit yang disebabkan oleh virus yang sering disebut virus Corona. Kasus ini muncul pertama kali di kota Wuhan, Cina pada Desember 2019 sehingga sering disebut covid-19. Penularan terjadi dengan sangat cepat dan menyebar ke berbagai negara termasuk Indonesia. Penyebaran yang sangat cepat menyebabkan berbagai upaya harus dilakukan untuk mencegah penyebaran lebih lanjut. Berbagai kebijakan pemerintah telah dilakukan diantaranya memberlakukan lockdown, Pembatasan Sosial Berskala Besar (PSBB) dan Pemberlakukan Pembatasan kegiatan Masyarakat (PPKM).

Di Indonesia penyebaran virus corona tidak hanya pada masyarakat perkotaan tetapi juga pedesaan. Kurangnya pengetahuan dan tingkat kepatuhan pada protokol kesehatan menyebabkan virus ini cepat menyebar. Orang Tanpa Gejala (OTG) adalah orang yang tidak menunjukkan adanya gejala terinfeksi tetapi memiliki risiko tertular dari orang yang terkonfirmasi positif covid 19. Melakukan pencegahan adalah solusi yang terbaik. WHO merekomendasikan untuk meminimalkan penularan diantaranya mencuci tangan dengan sabun minimal 20 detik, atau dengan penggunaan desinfektan (Mahmood et al., 2020; WHO, 2009).

Desinfektan dan hand sanitizer merupakan bahan kimia yang sering digunakan untuk pencegahan penularan virus corona. Bahkan pada awal berkembangnya virus corona di Indonesia, kedua bahan tersebut sangat sulit diperoleh. Berbagai informasi pembuatan desinfektan dan hand sanitizer mudah diperoleh masyarakat secara online tanpa diketahui kebenarannya atau belum dilakukan uji ilmiahnya. Pembuatan desinfektan dan hand sanitizer sendiri tanpa memiliki pengetahuan yang cukup justru memiliki resiko terhadap kesehatan. Kesalahan yang terjadi diantaranya takaran yang tidak pas, menyebabkan bahan aktif tidak mempan membunuh mikroba. Efek jika kebanyakan akohol menyebabkan tangan menjadi kering.

Menurut WHO bahwa penggunaan cairan desinfekstan dengan cara menyemprotkan ke selurh bagian tubuh memberikan efek kerusakan selaput lendir seperti mata dan mulut. Demikian juga menghirup gas yang dihasilkan desinfektan seperti gas klorin dan klorin dioksida memiliki dampak kerusakn pada saluran pernafasan. Bahan aktif antiseptik klorosilenol apabila terhirup menyebakan gangguan kesehatan bahakan kematian. Bahan aktif lain yaitu benzalkonium klorida dapat menyebabkan iritasi mata (Li et al., 2020).

Salah satu jenis tumbuhan yang banyak dibudidayakan pada daerah tropis dan subtropis seperti wilayah Asia, Afrika dan Amerika (Chanthal et al., 2012). Batang serai biasanya digunakan sebagai rimpang, sedang daun serai belum banyak dimanfaatkan. Daun serai mengandung tanin, flavonoid, alkaloid dan minyak atsiri (Shresta and Khadka., 2020). Hasil penelitian Azolbaay et al. (2018), ekstrak daun serai memiliki sifat antibakteri terhadap bakteri gram positif (Bacillus cereus, Staphylococcus aureus dan Micrococcus spp.) dan bakteri gram negatif (Pseudomonas spp. Escherichia coli dan Salmonella typhimurium). Kegiatan pengabdian masyarakat sebelumnya telah mengekstrasi daun serai untuk mengusir nyamuk (Hariani et al., 2016).

Kegiatan pengabdian masyarakat ini memberikan pelatihan cara membuat desinfektan dan hand sanitizer dengan penambahan ekstrak daun serai pada masyarakat dusun IV, desa Tanjung Seteko, Indralaya, Ogan Ilir. Masyarakat dusun ini memiliki tingkat pendidikan yang beragam dari SD sampai perguruan tinggi. Demikian juga pekerjaan, sebagai petani, pedagang, buruh, pegawai negeri dII. Lokasi dusun IV dekat dengan pasar, pertokoan, perkantoran dll. Pada kondisi pandemic covid 19 ini, sebagian aktivitas masyarakat masih berjalan normal terutama karena faktor ekonomi seperti bertani, berdagang di pasar, dan penarik bentor. Pekerjaan tersebut sangat berpotensi terjadinya penularan. 


\section{METODE KEGIATAN}

Kegiatan Pengabdian kepada masyarakat dilakukan di dusun IV, desa Tanjung Seteko, Indralaya, Ogan Ilir. Lokasi desa ini pada pusat keramaian seperti perkantoran, pasar, dan fasilitas umum lainnya.

Metode pelaksanaan kegiatan terbagi dalam beberapa tahap yaitu: pelatihan ekstraksi daun serai menggunakan etanol secara maserasi, pelatihan cara membuat desinfektan dan hand sanitizer, dan evaluasi. Evaluasi diberikan pada khalayak sasaran dengan memberikan kuis pada masyarakat. Evaluasi dilakukan terhadap pemahaman masyarakat terhadap bahaya virus covid-19, ketrampilan masyarakat dalam pembuatan desinfekatan dan hand sanitizer serta sikap masyarakat setelah kegiatan pengabdian masyarakat dilaksanakan.

Ekstraksi daun serai dilakukan dengan cara maserasi yaitu sebanyak $1000 \mathrm{~g}$ daun serai segar dengan 2 L etanol $96 \%$. Campuran direndam selama 24 jam. Selanjutnya disaring sehingga diperoleh ekstrak daun serai. Pembuatan desinfektan sebagai berikut sebanyak 3,64 L ekstrak etanol ditambahkan akuademin hingga volume 5,0 L. Sebanyak 12,5 g natrium hipoklorit ( $\mathrm{NaOCl}$ ) dimasukan larutan tersebut, diaduk sampai homogen. Pembuatan hand sanitizer dilakukan dengan cara mencampurkan sebanyak $833 \mathrm{~mL}$ ekstrak etanol daun serai dan $41,7 \mathrm{~mL}$ hidrogen peroksida $\left(\mathrm{H}_{2} \mathrm{O}_{2}\right) 3$ $\%$, diaduk agar homogen. Selanjutnya ditambahkan $14,5 \mathrm{~mL}$ gliserol, 0,5 g carbopol dan 2-3 tetes TEA, campuran diaduk kembali hingga homogen. Selanjutnya didiamkan selama 72 jam.

\section{HASIL DAN PEMBAHASAN}

Serangkaian kasus radang pernafasan yang terjadi di kota Wuhan, memiliki kemiripan dengan gejala klinis yang dialami penderita virus pneumonia (WHO, 2009). Analisis terhadap sampel dari saluran pernapasan bagian bawah menunjukkan adanya virus corona baru (Huang et al., 2020). Virus ini telah diidentifikasi dengan genom sequencing pada laboratorium di Cina sebagai 2019-nCoV dengan nama penyakit Covid-19 (Zhang et al., 2020). Di Indonesia 34 propinsi sudah terdampak virus covid-19. Sumatera Selatan termasuk salah satu propinsi dengan jumlah pasien positiv covid-19 termasuk urutan 10 besar. Tindakan pencegahan dan gaya hidup sehat untuk menjaga sistem imunitas tubuh disarankan untuk mencegah Covid-19. Salah satu gaya hidup sehat yang penting adalah menjaga kebersihan tangan, menjaga jarak dan menggunakan masker.

Kegiatan pengabdian masyarakat adalah pelatihan pembuatan desinfektan dan hand sanitizer dengan penambahan aroma alami dari ekstrak daun serai yang dilaksanakan di dusun IV, desa Tanjung Seteko, Indralaya, Ogan Ilir. Khalayak sasaran sebanyak 40 orang yang didominasi ibu-ibu dan remaja putri, dengan usia 17-65 tahun. Lokasi dusun tersebut terletak pada daerah dekat keramaian seperti pasar, perkantoran dan fasilitas umum, sehingga kegiatan ini penting untuk dilaksanakan. Sebelum pelaksanaan pelatihan disebarkan kuis untuk mendapatkan gambaran pengetahuan masyarakat terhadap virus covid-19 seperti tercantum pada Tabel 1.

Tabel 1 Distribusi Pengetahuan masyarakat tentang virus covid-19

\begin{tabular}{lccc}
\hline \multicolumn{1}{c}{ Pertanyaan } & Benar (\%) & Salah (\%) & Tidak paham (\%) \\
\hline $\begin{array}{l}\text { Virus covid-19 adalah tidak berbahaya, } \\
\text { seperti halnya flu biasa }\end{array}$ & 65 & 30 & 5 \\
$\begin{array}{l}\text { Virus covid-19 tidak akan menular ketika } \\
\text { berbicara kecuali berinteraksi secara fisik }\end{array}$ & 82,5 & 12,5 & 5 \\
$\begin{array}{l}\text { Orang yang menularkan virus covid-19 } \\
\text { adalah yang memiliki gejala }\end{array}$ & 87,5 & 12,5 & 0 \\
$\begin{array}{l}\text { Gejala orang yang terkena virus covid-19 } \\
\text { lebih berat pada usia tua atau memiliki } \\
\text { penyakit bawaan atau penyakit kronis }\end{array}$ & 62,5 & 12,5 & 25 \\
$\begin{array}{l}\text { Anak-anak tidak termasuk kelompok usia } \\
\text { yang beresiko terkena covid-19 }\end{array}$ & 35 & 35 & 30 \\
\hline
\end{tabular}




\begin{tabular}{lccc}
\hline $\begin{array}{l}\text { Orang yang sehat atau tidak memiliki gejala } \\
\text { tidak perlu menggunakan masker ketika }\end{array}$ & 75 & 20 & 5 \\
$\begin{array}{l}\text { keluar rumah } \\
\text { Kondisi saat ini virus covid-19 sudah mereda }\end{array}$ & 75 & 25 & 0 \\
\hline
\end{tabular}

Berdasarkan Tabel 1 tampak bahwa pemahaman masyarakat terhadap virus covid- 19 masih sangat kurang. Anggapan masyarakat bahwa virus covid-19 tidak berbahaya sangat keliru, masyarakat tetap harus waspada dan menjalani protokol kesehatan. Pemahaman masyarakat bahwa orang yang menularkan virus covid-19 adalah yang memiliki gejala sangat keliru. Pada saat ini, banyak sekali orang terindikasi terjangkit virus covid-19 tetapi hanya menunjukkan gejala ringan atau bahakan tidak memiliki gejala. Sebanyak 25 \% (10 orang) tidak memahami bahwa risiko virus covid-19 lebih besar pada usia tua dan orang memiliki penyakit bawaan atau penyakit kronis. Semakin lemah kondisi tubuh maka semakin mudah terinfeksi virus covid-19. Hasil penelitian menunjukkan bahwa orang dengan mengidap penyakit menahun tidak hanya beresiko terinfeksi tetapi juga memiliki risiko kematian. Hal ini terjadi karena mereka tinggal pada daerah tergolong zona merah atau lingkungan yang banyak terkonfirmasi covid-19. Masyarakat juga harus memahami gejala klinis yang timbul akibat terinfeksi virus covid-19. Kurangnya pemahaman masyarakat terhadap virus covid-19 dan tidak mengikuti protokol kesehatan dapat menjadikan Indonesia sebagai episentrum baru virus covid-19. Penularan dapat terjadi dari manusia ke manusia lain melalui kontak secara fisik dan percikan-percikan dari mulut dan hidung, penularan juga dapat terjadi melalui udara berupa aerosol (Li et al., 2020; Chan et al., 2020). Kemungkinan penularan juga ditunjukkan oleh pembawa asimtomatik (Biscayart et al., 2020).

Tabel 2 Distribusi perilaku masyarakat tentang protokol kesehatan

\begin{tabular}{lcc}
\hline \multicolumn{1}{c}{ Pertanyaan } & Benar (\%) & Salah (\%) \\
\hline $\begin{array}{l}\text { Masyarakat terbiasa mencuci sabun setalah berpergian, memegang benda } \\
\text { di tempat umum }\end{array}$ & 8020 \\
Masyarakat mengetahui perbedaan penggunaan desinfektan dan hand & 10 & 90 \\
sanitizer dengan tepat & & 85 \\
Masyarakat selalu membawa hand sanitizer jika berpergian ke luar rumah & 15 & 27,5 \\
Masyarakat menggunakan masker jika keluar rumah & 20 & 80 \\
Masyarakat selalu menjaga jarak (minimal 1 m) jika dengan orang lain & 40 & 60 \\
Masyarakat memahami untuk menghindari kegiatan yang bersifat & & 87,5 \\
berkumpul dalam jumlah banyak & 12,5 & \\
Masyarakat mengerti istilah new normal dengan tepat & & \\
\hline
\end{tabular}

Tabel 2 menunjukkan gambaran perilaku masyarakat terhadap protokol kesehatan, pemahanan terhadap desinfektan dan hand sanitizer. Secara umum, masyarakat sudah memahami pentingnya mencuci tangan menggunakan sabun setelah berpergian, atau memegang benda di tempat umum. Hal ini tidak lepas dari banyaknya slogan agar masyarakat selalu menjaga kebersihan dengan rajin mencuci tangan agar terhindar dari tertularnya virus covid-19. Namun, sebagian besar masyarakat belum memahami perbedaan penggunaan desinfektan dan hand sanitizer. Masyarakat juga belum terbiasa menggunakan desinfektan dan hand sanitizer. Istilah new normal sudah sering mereka mendengar, namun pengertian seeanarnya masyarakat belum memahami. Akibatnya masyarakat melakukan aktivitas dan berkumpul seperti semula saat sebelum pandemi meskipun sebagian besar menggunakan masker.

Kegiatan selanjutnya adalah memberikan pemahaman tentang virus covid-19, pelatihan pembuatan desinfektan dan hand sanitizer. Gambar 1 menunjukkan tim pengabdian sedang memberikan pelatihan cara membuat desinfektan dan hand sanitizer dengan penambahan ekstrak daun serai. Desinfektan dan hand sanitizer dibuat sesuai standar WHO. Bahan-bahan yang digunakan untuk membuat desinfektan adalah natrium hipoklorit, ekstrak daun serai menggunakan air, dengan 
komposisi natrium hipoklorit $0,5 \%$. Hand sanitizer dibuat dari ekstrak daun serai yang diekstrak menggunakan etanol, gliserol, dan $\mathrm{H}_{2} \mathrm{O}_{2} 3 \%$. Bahan aktif hand sanitizer adalah $\mathrm{H}_{2} \mathrm{O}_{2}$, dan etanol berfungsi sebagai pelarut dan bersifat bakterisidal, sebagai pelindung terhadap kulit terhadap infeksi mikroorganisme (Shu, 2013), etanol juga bermanfaat memberikan efek dingin atau segar pada tangan dan membantu agar cepat kering, agar kulit tetap lembab dan tidak kering maka digunakan gliserol, sedangkan carbopol dan TEA merupakan kombinasi untuk membuat gel dan pengaturan $\mathrm{pH}$.

Penambahan ekstrak daun serai menambah sifat anti bakteri (Jafari et al., 2012). Hasil penelitian Alzoobay et al (2018) bahwa ekstrak daun serai memiliki aktivitas anti bakteri terhadap bakteri gram positiv dan negativ. Daya hambat paling besar terhadap bakteri Staphylococcus aureus yaitu $28 \mathrm{~mm}$. Salah satu kandungan ekstrak daun serai adalah flavonoid, yaitu metabolit sekunder yang terdapat pada tumbuhan. Flavonoid merupakan senyawa yang berfungsi sebagai antibakteri, antialergi, sitotoksit dan antihipertensi (Nuryadin et al., 2018). Selain penyuluhan pada masyarakat juga diberikan video cara pembuatan desinfektan dan hand sanitizer, dengan harapan jika lupa bahan, komposisi dan prosedurnya maka dapat membuka video. Gambar 2 menunjukkan video pembuatan serta produk desinfektan dan hand sanitizer .

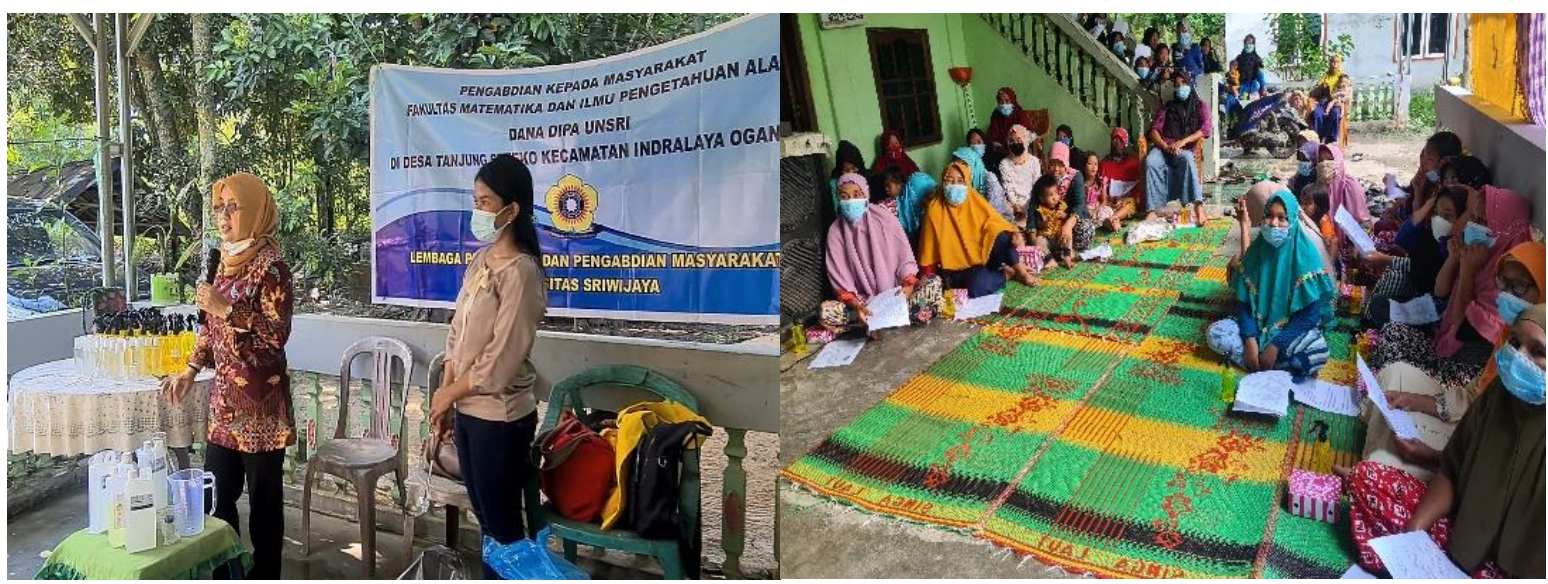

Gambar 1 Kegiatan penyuluhan dan pelatihan pembuatan desinfektan dan hand sanitizer

Pada kegiatan ini produk desinfektan dan hand sanitizer ditambahkan ekstrak daun serai, ekstrak daun serai juga memberikan aroma yang menyegarkan. Desinfektan tanpa ekstrak serai memiliki bau yang lebih menyengat, karena mengandung natrium hipoklorit. Desinfektan dikemas pada botol spray sehingga mudah digunakan untuk penyemprotan benda-benda yang sering dipegang seperti daun pintu, meja, lemari dll, sedangkan hand sanitizer karena berbentuk gel maka digunakan botol fliptop.

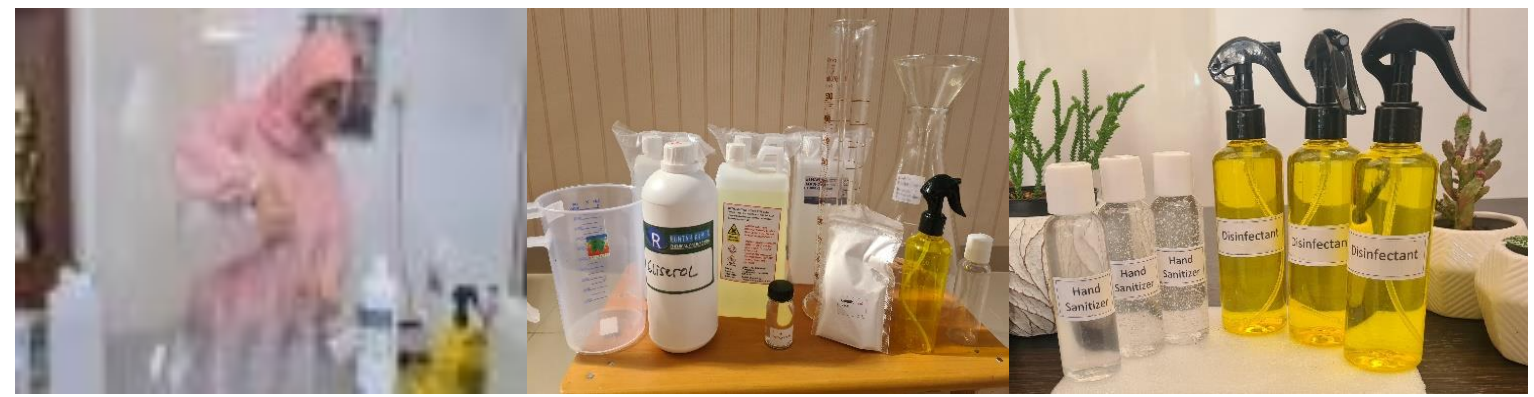

Gambar 2 Video pembuatan desinfektan dan hand sanitizer, bahan, serta produk desinfektan dan hand sanitizer 
Gambar 3 menunjukkan peningkatan rata-rata pengetahuan, ketrampilan dan sikap hasil kuis terhadap khalayak sasaran. Pengetahuan berkaitan dengan pemahaman masyarakat terhadap virus covid-19 sebelum dan sesudah pelatihan. Pengetahuan masyarakat terutama tentang transmisi virus covid-19 sangat bermanfaat untuk menekan laju pertambahan penularan. Ketrampilan berkaitan dengan kemampuan masyarakat membuat desinfektan dan hand sanitizer. Sikap adalah keinginan masyarakat atau perilaku yang akan dilakukan sesuai protokol kesehatan. Sebanyak $100 \%$ masyarakat menyatakan akan melakukan perilaku hidup sesuai protokol kesehatan untuk menghindari tertularnya oleh virus covid-19.

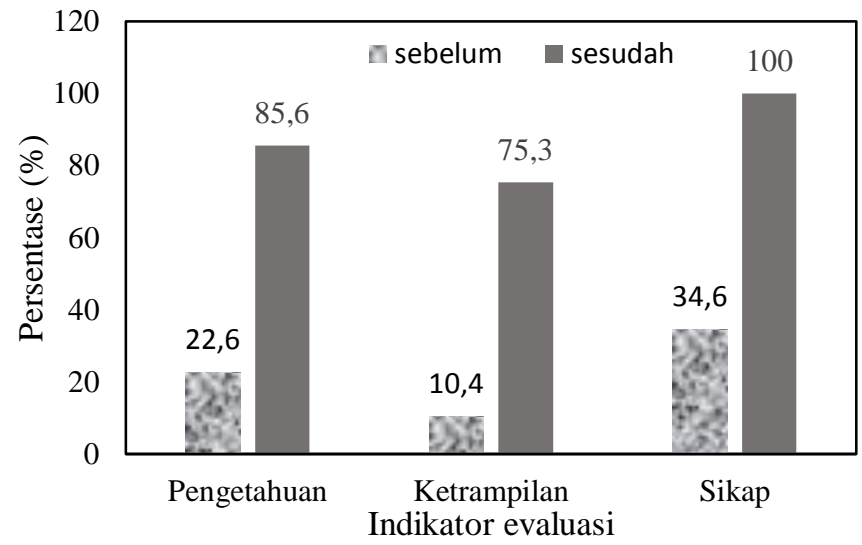

Gambar 3 Distribusi perubahan pengetahuan, ketrampilan dan sikap masyarakat sebelum dan sesudah pelatihan

\section{KESIMPULAN DAN SARAN}

Kesimpulan hasil kegiatan pengabdian masyarakat dengan judul Pelatihan pembuatan desinfektan dan hand sanitizer dengan penambahan aroma alami sebagai upaya pencegahan penularan virus covid-19 pada masyarakat dusun IV desa Tanjung Seteko, Indralaya, Ogan Ilir menunjukkan peningkatan pemahaman masyarakat terhadap virus covid-19, meningkatnya ketrampilan pembuatan desinfektan dan hand sanitizer serta perubahan sikap dan tingkah laku masyarakat untuk menjaga kebersihan dan mengikuti protokol kesehatan.

Saran untuk kegiatan selanjutnya adalah dapat digunakan aroma alami sumber tanaman yang lain, Indonesia terkenal dengan keanekaragaman hayati sebagai sumber tanaman obat.

\section{UCAPAN TERIMA KASIH}

Ucapan terimakasih pada Universitas Sriwijaya yang telah memberikan dana pelaksanaan kegiatan Pengabdian pada Masyarakat melalui hibah Aplikasi Iptek dan Pengembangan Seni Budaya Lokal, kontrak No. 0018.145/UN9.SB3.LP2M.PM/2020.

\section{DAFTAR PUSTAKA}

Biscayart, C., Angeleri, P., Lloveras, S., Chaves, T. D. S. S., Schlagenhauf, P., \& Rodríguez-Morales, A. J. (2020). The next big threat to global health? 2019 novel coronavirus (2019-nCoV): What advice can we give to travellers? - Interim recommendations January 2020, from the Latin-American society for Travel Medicine (SLAMVI). Travel Medicine and Infectious Disease, 33(1), 1-4.

Chan, J. F. W., Yuan, S., Kok, K. H., To, K. K. W., Chu, H., Yang, J., Xing, F., Liu, J., Yip, C. C. Y., Poon, R. W. S., Tsoi, H. W., Lo, S. K. F., Chan, K. H., Poon, V. K. M., Chan, W. M., Ip, J. D., Cai, J. P., Cheng, V. C. C., Chen, H., ... Yuen, K. Y. (2020). A familial cluster of pneumonia associated with the 2019 novel coronavirus indicating person-to-person transmission: a study of a family cluster. The Lancet, $395:$ :514-523. 
Chanthal, S., Prachakoli, S., \& Ruangviriyachai, C. (2012). Influence of extraction methodologies on the analysis of five major volatile aromatic compounds of citronella grass and lemongrass grown in Thailand. Journal of AOAC Internasional, 95: 763-772.

Hariani, P. . L., Said, M., Salni, \& Riyanti, F. (2016). Pelatihan Pembautan Obat Nyamuk Spray dari Ekstrak daun Serai.

Huang, C., Wang, Y., Li, X., Ren, L., Zhao, J., Hu, Y., Zhang, L., Fan, G., Xu, J., Gu, X., Cheng, Z., Yu, T., Xia, J., Wei, Y., Wu, W., Xie, X., Yin, W., Li, H., Liu, M., ... Cao, B. (2020). Clinical features of patients infected with 2019 novel coronavirus in Wuhan, China. The Lancet, 395: 497-506.

Jafari, B., Amirreza, E., Babak, M. A., \& Zarifeh, N. H. (2012). Antibacteria Activities of Lemon Grass Methanol Extract and Essence Pathogenic Bacteria. American-Eurasian Journal of Agricultural and Environmental Sciences, 12(8), 1042-1046.

Li, Q., Guan, X., Wu, P., Wang, X., Zhou, L., Tong, Y., Ren, R., Leung, K. S. M., Lau, E. H. Y., Wong, J. Y., Xing, X., Xiang, N., Wu, Y., Li, C., Chen, Q., Li, D., Liu, T., Zhao, J., Liu, M., ... Feng, Z. (2020). Early Transmission Dynamics in Wuhan, China, of Novel Coronavirus-Infected Pneumonia. The New England Journal of Medicine, 382: 1199-1207.

Mahmood, A., Eqan, M., Pervez, S., Alghamdi, H. A., Tabinda, A. B., \& Yasar, A. (2020). Hazards by exposure pathways. Science of The Total Environment, 742: 1-8.

Nuryadin, Y., Naid, T., Dahlia, A. ., \& Dali, S. (2018). Kadar Flavonoid Total Ekstrak Daun Serai Dapur Dan Alang-alang Menggunakan Spektrofotometeri UV-Vis. Jurnal Kesehatan, 1(4), 337-345.

Shu, M. (2013). Formulasi Sediaan Gel Hand Sanitizer dengan Bahan Aktif Triklosan 0,4 \% dan 1 \%. Jurnal IImiah Mahasiswa Universitas Surabaya, 2(1), 1-14.

WHO. (2009). Guidelines on Hand Hygiene in health care: first global patient safety challenge: clean care is safer care. WHO (World Health Organization) : Geneva, Switzerland.

Zhang, N., Wang, L., Deng, X., Liang, R., Su, M., He, C., Hu, L., Su, Y., Ren, J., Yu, F., Du, L., \& Jiang, S. (2020). Recent Advances in the Detection of Respiratory Virus Infection in Humans. Journal of Medical Virology, 92 : 408-417. 